Proceeding Paper

\title{
Solar Powered DC Refrigerator for Small Scale Applications ${ }^{\dagger}$
}

\author{
Muhammad Waqas Jabbar*(D), Mirza Hassan Naeem, Asad Muneer, Usama Rehman and Tayyab Riaz \\ Department of Electrical Engineering, Hafiz Hayat Campus, University of Gujrat, Gujrat 50700, Pakistan; \\ 18103322-041@uog.edu.pk (M.H.N.); asad.muneer@uog.edu.pk (A.M.); 18103322-019@uog.edu.pk (U.R.); \\ 18813322-007@uog.edu.pk (T.R.) \\ * Correspondence: waqas.jabbar@uog.edu.pk \\ † Presented at the 1st International Conference on Energy, Power and Environment, Gujrat, Pakistan, \\ 11-12 November 2021.
}

check for

updates

Citation: Jabbar, M.W.; Naeem, M.H.;

Muneer, A.; Rehman, U.; Riaz, T.

Solar Powered DC Refrigerator for Small Scale Applications. Eng. Proc. 2021, 12, 98. https://doi.org/ 10.3390/engproc2021012098

Academic Editor: Muzaffar Ali

Published: 14 February 2022

Publisher's Note: MDPI stays neutral with regard to jurisdictional claims in published maps and institutional affiliations.

Copyright: (C) 2022 by the authors. Licensee MDPI, Basel, Switzerland. This article is an open access article distributed under the terms and conditions of the Creative Commons Attribution (CC BY) license (https:// creativecommons.org/licenses/by/ $4.0 /)$.

\begin{abstract}
Due to the gradatory reduction and exuberant ingestion of fossil fuels and the subsequent environmental problems, accretive work has been paid to the utilization of renewable energy sources, such as solar energy. Solar Photovoltaic System or Solar Power System is one of the renewable energy systems which uses PV units to convert sunlight into electricity. A DC compressor of $12 \mathrm{~V} / 80 \mathrm{~W}$, $12 \mathrm{~V} / 50$ Ah battery, a pair of $12 \mathrm{~V} / 175 \mathrm{~W}$ solar panels connected in parallel through a 10 A charge controller was used for the refrigerator. Temperature was programmed to monitor and control the switching states of the DC compressor. This research project has established that the energy required for the real process of a DC refrigerator could be amassed from a renewable energy source at a reduced price and its application can be beneficial in developing countries. ATMEGA16 microcontroller with temperature, weight and momentary sensors interfacing was programmed in $C$ language to control and monitor the ON/OFF states of the DC compressor. In this work, energy can be obtained from renewable energy resources at a reduced cost for the effective operation of a DC refrigerator. Thus, developing countries can also take benefit from its applications.
\end{abstract}

Keywords: solar panel; Arduino UNO; DC compressor; refrigerant; aluminum sheet; Foam

\section{Introduction}

Ref. [1] Solar energy has gained a lot of importance in this eco-friendly, sustainable environment and energy demand for its users is increasing day by day. This energy can be used to power up the refrigerator. Frequent and long-term power disruption can cause difficulties in developing countries to maintain and preserve blood banks, vaccines and perishable food. Locations that are very far away from the supply grids can be affected immensely.

In refrigeration, the temperature of the components is being lowered below the immediate temperature to reserve or make them suitable for future use. The growth of microorganisms is greatly reduced when food is stored in the refrigerator at temperatures below freezing. Ref. [2] In this regard, complete failure of cells and fiber in nutrition is prevented. Additionally, the fluid loss and rate of rust through evaporation is reduced. With a constant temperature range, the refrigerator provides significant injection strength and blood quality $[3,4]$.

The objective of this article is to demonstrate the importance of combining renewable energy sources to power up the refrigerator system, which are of low cost and high efficiency. This was achieved using a DC compressor that also runs directly on the demarcated voltage through the battery or the charge controller through the sun, thus eliminating the components of the inverter. Microprocessor-based control and monitoring systems provide energy savings and flexible use of the refrigerator $[5,6]$.

The remaining parts of the paper are as follows: The required Methods and Materials are presented in Section 2. In Section 3, the purpose of content size is calculated and presented. The results are presented in Section 4 , and Section 5 covers the endings and 
definitions of the solar refrigerator system of the solar panel that collects the solar energy. Solar panels consist of photovoltaic cells that convert solar light into electrical energy and this energy is stored in batteries. The electricity is supplied directly through the solar panel in normal conditions, the excess power is supplied by the battery when the output power of the solar panels decreases. The battery recharges when more electricity is generated from solar panels. The $12 \mathrm{~V}$ DC is applied as output supply from batteries and solar panels. A total of $300 \mathrm{~W}$ or $600 \mathrm{~W}$ of electricity is produced by a typical solar panel, and it depends upon the size of the refrigerator required [7]. The compressor is connected to a voltage regulator battery to convert a low voltage DC supply to a high voltage AC supply. It is effective and beneficial to utilize the AC supply compressor as it can also run-on household power supply. Few of the solar refrigerators use compressors that can operate on DC voltage directly. This research work is related to the different renewable energy resources where people are also focusing on developing the applications that use renewable energy [8] This work is used to generate electricity for cooling; therefore, this is achievable work. This research project is cost effective and provides benefits for future applications.

\section{Methods and Materials}

It has a simple refrigerant (Ra134) with flat plate pre-compressor having a maximum temperature of $120^{\circ} \mathrm{C}$. Heat is packed in this collector and contains copper vessels that have refrigerant. The refrigerant is compressed by heat packed in a flat plate collector. To flow the refrigeration in one direction, a small 1/8 HP $12 \mathrm{~V}$ DC compressor is used which is energized by a 100-watt PV system. The greater the solar radiation is outside in the environment, the greater its cooling will be. A 150-watts solar refrigerator will approximately provide a temperature of $2{ }^{\circ} \mathrm{C}$. Materials specifications are:
1. Flat plate $1.64 \mathrm{ft}^{3}$
2. Evaporator temperature $=2{ }^{\circ} \mathrm{C}$
3. Evaporator Size $=1.64 \mathrm{ft}^{3}$
4. DC compressor $1 / 10$ th HP
5. Refrigerant: R134a, PV $=150$ Watt

This project totally works on solar energy and have a battery backup. Figure 1 shows the simple block diagram in which a solar panel, battery and controller are used for this work.

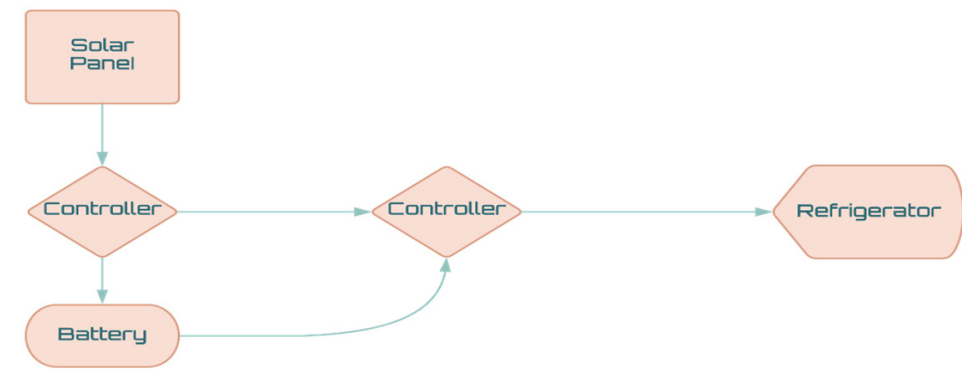

Figure 1. Simple block diagram of the refrigerator.

The procedure is divided into five stages: preparation, research, examination, designing and implementation. The planning phase is the basic process of understanding why a system should be built and deciding where to build it. This step will ensure that all activities will be on time as the system develops. The research phase is where all the relevant information for this project is to be gathered. The study includes a feasibility study on solar geometry, solar energy, feasibility of using solar energy for cooling, steam cooler systems, heat sources and cooling load. Analysis is where many factors/ideas are considered before implementing the system. This phase includes a description of the input and output process, cooling load analysis, device size analysis and equipment space analysis. The design phase determines how the system will work. All the mechanisms 
required for a steam powered solar cooler system must be stated. The design should be analyzed for best performance with low rate and low power.

\section{Solar PV System Sizing}

\subsection{Determine Power Consumption Demands}

The first step in designing a solar PV system is to find out the total power and energy consumption of all loads that need to be supplied by the solar PV system as follows:

$$
\begin{aligned}
\text { Ampere } & =\mathrm{KVA} \times 1000 \mathrm{E} \\
\mathrm{Ed} & =\mathrm{Ced} \times \mathrm{hr}
\end{aligned}
$$

where Ced is the hourly energy demand and hr is the number of hours.

\subsection{Calculate Total Watt-Hours per Day for Each Appliance Used}

Add the Watt-hours needed for all appliances together to get the total Watt-hours per day which must be delivered to the appliances:

$$
\text { kwh consumption }=\text { Watts } \times \text { Hours used per days } / 1000
$$

\subsection{Calculate Total Watt-Hours per Day Needed from the PV Modules}

Multiply the total appliance's Watt-hours per day times 1.3 (the energy lost in the system) to get the total Watt-hours per day which must be provided by the panels:

$$
\mathrm{kwh}=\text { Watts } \times \text { Time }(\mathrm{Hrs}) /\{1000\}
$$

\subsection{Battery Sizing}

To find out the size of battery, calculate as follows:

$$
\begin{gathered}
\mathrm{Cb}=\text { Volts } \times \text { Ampere }(\mathrm{Hrs}) /(100) \\
\mathrm{E}_{\text {est }}=\mathrm{E}_{\mathrm{d}} \times \mathrm{Dsv}
\end{gathered}
$$

where Daut is the number of days of sovereignty (i.e., the number of days the battery bank should supply without charging).

Nonviolent energy stored:

$$
\mathrm{E}_{\mathrm{nv}}=\mathrm{E}_{\mathrm{nv}} / \mathrm{D}_{\mathrm{dis}}
$$

The number of modules in series is given by (7) and the number of modules in parallel is given by:

$$
\begin{gathered}
\mathrm{Nms}=\mathrm{Vdc} / \mathrm{Vpm} \\
\mathrm{Nmp}=\mathrm{Vdc} / \mathrm{Vp}
\end{gathered}
$$

\section{Results and Discussion}

The result of the first test carried out determines the time taken for water to freeze:

$$
\text { Initial temperature of water }=30\left({ }^{\circ} \mathrm{C}\right) \text {, Time interval }=20 \mathrm{~min}
$$

Realistic view of the refrigerator with a solar panel, charge controller and battery. Power sterilization to operate the refrigerator depends on its actual temperature and the set value of the temperature to be stored. Table 1 shows the results on testing the refrigerator on a typical day, after charging the battery volt is 12.77 at about 7:00 a.m., on switching ON the refrigerator the starting current is about $5.30 \mathrm{~A}$ and the power consumed was $67.16 \mathrm{~W}$ that was measured by multimeter. This reading was measured when the refrigeration early temperature was about $26^{\circ} \mathrm{C}$ and the predetermined temperature is $9{ }^{\circ} \mathrm{C}$ as programmed into the Microprocessor. As time goes on at night, the battery voltage drops because the 
sun was no longer there to charge. It has also been observed that as the temperature drops, the power consumption also decreases while the default temperature is maintained to a considerable extent. The battery starts to charge as soon as the sun rises the next day. The results show that, once the default temperature is reached, the power consumption is quite stable, and when the battery is fully charged, the system can be continued overnight.

Table 1. (Power feeding, current and power drop).

\begin{tabular}{|c|c|c|c|c|c|}
\hline Time & Battery Voltage (V) & $\begin{array}{l}\text { Compressor and } \\
\text { Fan Current (A) }\end{array}$ & $\begin{array}{l}\text { Compressor and } \\
\text { Fan Voltage (V) }\end{array}$ & $\begin{array}{c}\text { Power } \\
\text { Consumption (W) }\end{array}$ & Temperature $\left({ }^{\circ} \mathrm{C}\right)$ \\
\hline 7:00 a.m. & 12.77 & 5.30 & 12 & 67.16 & 26.0 \\
\hline 9:00 a.m. & 12.61 & 3.55 & 12 & 42.30 & 25.0 \\
\hline 12:00 a.m. & 11.78 & 2.97 & 12 & 35.60 & 17.0 \\
\hline 3:00 a.m. & 11.26 & 2.71 & 12 & 32.80 & 12.0 \\
\hline 7:00 p.m. & 13.82 & 2.65 & 12 & 32.02 & 9.0 \\
\hline 11:00 p.m. & 14.12 & 2.58 & 12 & 31.60 & 9.1 \\
\hline 1:00 a.m. & 13.12 & 2.56 & 12 & 31.05 & 9.6 \\
\hline
\end{tabular}

\section{Conclusions}

To reduce costs, renewable energy can be used for DC refrigerators and this article shows this applicability. In this work, losses are minimized, and power consumption is reduced as an average of $30.21 \mathrm{~W}$. The operation of the system is enhanced and made efficient by using monitoring and control of the refrigerator. Power supply to the refrigerator was disconnected whenever the open, empty unit or overload was detected. The devices used in homes, workplaces, hospitals, etc., can be directly powered with low power using DC sources. DC power refrigerators should be promoted in rural areas and in hospitals. The cooling effect is not good in this work because casing is not airtight, and it does not give an ideal system. To remove this issue, a new approach is advised to make better casing.

Author Contributions: Conceptualization, M.H.N. and M.W.J.; methodology, M.H.N. and U.R.; validation, M.H.N., T.R., U.R.; formal analysis, M.W.J.; investigation, M.H.N.; data curation, T.R., U.R.; writing—original draft preparation, M.H.N., M.W.J.; writing—review and editing, A.M., M.W.J.; supervision, M.W.J. All authors have read and agreed to the published version of manuscript.

Funding: This research received no external funding.

Institutional Review Board Statement: Not applicable.

Informed Consent Statement: Not applicable.

Data Availability Statement: Not applicable.

Conflicts of Interest: The authors declare no conflict of interest.

\section{References}

1. American Society for Heating: Fundamental Handbook, Refrigeration and Air Conditioning for Engineers; Ashrae Publishing: Peachtree Corners, GA, USA, 1977; p. 272.

2. Anderson, O.E. Refrigeration in America; Princeton University Press: Princeton, NJ, USA, 2015.

3. Aprea, C.; Mastrullo, R.; De Rossi, F. Behaviour and performances of R502 alternative working fluids in refrigerating plants. Int. J. Refrig. 1996, 19, 257-263. [CrossRef]

4. Wilson, D.P.; Basu, R.S. Thermodynamic properties of a new stratospherically safe working fluid-refrigerant $134 a$. ASHRAE Trans. 1988, 94, 2095-2118.

5. Ungar, M.P. Fresh: A Perishable History; Harvard University Press: Cambridge, MA, USA, 2010; pp. 300-302.

6. Neuburger, A. The Technical Arts and Science of the Ancients; Kegan Paul: London, UK, 2003; p. 122.

7. Rajput, R.K. A Textbook of Engineering Thermodynamics; Laxmi Publications: New Delhi, India, 2005.

8. Deshmukh, S.D.; Kalbande, S.R. Performance evaluation of photovoltaic system designed for DC refrigerator. Int. J. Sci. Res. 2015, $4,18-23$. 